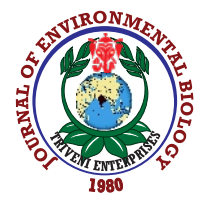

\title{
Native bee diversity and abundance in an urban green space in Bengaluru, India
}

\author{
V.R. Bhatta' and A.N. Kumar ${ }^{2 *}$ \\ 'Department of Zoology and Genetics, Jyoti Nivas College Autonomous, Bengaluru-560 095, India \\ 2Department of Zoology, Periyar University, Salem-636 011, India \\ *Corresponding Author Email : naresh.phd@gmail.com
}

\section{Abstract}

Aim: The aim of the present study was to estimate the diversity and abundance of native bee fauna in an urban green space in Bengaluru, India.

Methodology: Native bees were sampled from ten observational plots randomly selected from a 20 ha urban green space. Bee diversity and abundance were recorded at 15-day interval and estimated using diversity indices.

Results: Nineteen species and thirteen genera under Apidae, Halictidae, and Megachilidae family were recorded. Bee species under Apidae were the most abundant, with four social, five solitary, and one kleptoparasitic species, followed by Halictidae and Megachilidae, with five and four solitary bee species, respectively. Trigona iridipennis was the dominant species followed by Apis dorsata among the social bees, and Lasioglossum sp. and Hriades sp. were dominant among the solitary bees. The number of cavitynesting species was more that of tree-nesting or ground-nesting species. Shannon's and Simpson's diversity indices confirmed the species richness, species abundance, and uniform distribution of native bee species in the urban green space.

Interpretation: Green patches within urban areas can support a diverse population of bees. The study area consisted of both social and solitary bees. Cavity-nesting and oligolectic generalist bees were more predominant in the urban area, thus confirming the role of urban spaces in adding to bee diversity. Green pockets within urban areas support a diverse population of bees, and urban green spaces and green corridors can help to conserve bee biodiversity and, in turn, the urban ecosystem.

Key words: Apidae, Bee diversity, Diversity indices, Trigona iridipennis, Urban green spaces

How to cite : Bhatta, V.R. and A.N. Kumar: Native bee diversity and abundance in an urban green space in Bengaluru, India. J. Environ. Biol., 41, 1536-1541(2020). 


\section{Introduction}

Bees are an economically and ecologically important group of pollinators and their diversity is essential for the health of any ecosystem. The total number of bee species worldwide described so far is reported to be 17,553 , grouped under 443 genera and seven families (Michener, 2007). Of these, 633 species from 60 genera and six families are reported from India (Gupta, 2003). Bee diversity and richness ensure effective pollination of native and cultivated crops. (Kremen et al., 2002). Approximately, $75 \%$ of world's cultivated crops are pollinated by wild bees (Klein et al., 2007), and mutualism between plants and bees as evolved over centuries and has been helping both natural and man-made agro-ecosystems. Bee population and diversity are also vital bio-indicators of health of an environment (Kevan, 1999). In recent years, the decline in both wild and domesticated pollinators, and the parallel decline in plants that rely upon them, has been a matter of concern.

This decline threatens the stability and sustainability of ecosystems (Biesmeijer et al., 2006). Since bee diversity is directly associated with the diversity of flowering plants, loss of plant diversity can negatively affect bee species (Potts et al., 2003). Drastic decline in bee diversity and of plants they pollinate was also reported by Osborne et al. (1991) and Williams et al. (2009). A few studies have also indicated the extinction of native bee species owing to loss of floral resources (Cane et al., 2001; Winfree et al., 2007; Goulson et al., 2015). The habitat loss and habitat fragmentation resulting due to urbanization, urban expansion, landscape alteration, and agricultural intensification are among the major threats to pollinator (Kremen et al., 2007; Winfree et al., 2009; Williams et al., 2010). Although urbanization is considered a major threat to ecosystems, green spaces within the cities have shown a significant capacity to support bee diversity (Matteson et al., 2008; McDonald et al., 2008) compared to that shown by agricultural or natural ecosystems (Williams and Kremen, 2007; Badlock etal., 2015).

Changing agricultural landscapes, agricultural intensification, and monoculture resulting in lack of floral diversity have induced a shift in pollinator diversity consistent with heterogeneous floral components of urban green landscapes (Senapathi et al., 2015: Otto et al., 2016), and the positive impact of diverse urban floral resources and plant species richness on the bee community is well documented (Zapparoli, 1997; Grimm et al., 2008; Banaszak-Cibickaand Zmihorski, 2012). Therefore, fragmented green spaces within urban landscapes have become an important integral refuge for native bee biodiversity (Savard et al., 2000; Fetridge et al., 2008; Goddard et al., 2010). Human interventions in urban habitats have introduced highly diverse and exotic flora in managed habitats, and these measures ensure an abundant and multi-floral mix of nutritional sources for the survival and reproduction of bees (Frankie et al., 2005). Thus, urban green spaces with year-round availability of diverse floral resources (Harrison and Winfree, 2015) constitute isolated and constructed habitats in cities (Pardee and Philpott, 2014). Urban bee diversity also ensures pollination of many plant species that support animals that depend on bee-pollinated plants (Hausmann et al., 2016) Policy makers in the developed countries confronted with this problem have been promoting pollinator conservation extensively through urban agriculture and pollinator-friendly gardens (Colla etal., 2009; Tonietto etal., 2011).

Most of the urban bee diversity studies focus on green spaces within botanical parks, gardens, or semi-natural areas; however, no data are available on green spaces within dense human settlements or cities-data that can help us to understand the effect of human activity. In a rapidly developing country such as India, with unprecedented urbanization and urban expansion, bee diversity within urban habitats has been neglected. Moreover, there are no systematically documented data on urban bee fauna to assess the suitability of urban habitats. A comprehensive ecological understanding of pollinator diversity in urban green spaces is thus critical to understand the magnitude of urbanization and also to the management and conservation of such green spaces. Therefore, the primary objective of this study was to estimate the diversity and richness of native bees systematically in an urban green space in Bengaluru, the fastestdeveloping metropolitan city in India.

\section{Materials and Methods}

Study area: The study was conducted in a 20 ha urban green space available at the National Institute of Animal Nutrition and Physiology campus $\left(12^{\circ} 57^{\prime} 04.3^{\prime \prime} \mathrm{N}, 77^{\circ} 36^{\prime} 25.3^{\prime \prime} \mathrm{E}\right), 7 \mathrm{~km}$ from downtown Bengaluru.

Sample site characterization: The study area represented an ideal urban green space interspersed with impervious office and residential buildings. The site was selected because it represents a typical urban green space surrounded by densely populated buildings and, thus, suited to capture the diversity of bees under urban conditions in a habitat having reasonably diverse flora amidst human activity. The diverse mix of flora in the study area included lawns, kitchen gardens, ornamental flowering plants, and shrubs and trees (wild and cultivated) along with stretches of wild vegetation.

Sampling method: Ten randomly selected observational plots, each measuring $3 \mathrm{~m} \times 3 \mathrm{~m}$, were selected within the urban green space for the present study (Westphal et al., 2008). The observational plots were selected with enough care to represent different vegetation types available in the urban green space.

Sampling time: Sampling was carried out at 15-day interval for 6 months, from November 2017 to April 2018. Bees were sampled between 9.00 and 11.00 a.m. because their activity was maximum at that time (Reddy et al., 2015) owing to the climatic and flowering conditions being optimal. Diversity was assessed by counting, over $5 \mathrm{~min}$, the number of bees visiting the flowers (except trees) at each observational plot. The order in which the plots were visited was randomized so as to avoid any temporal bias. 
Collection and identification: Initially, bees were collected with the help of a sweep net, transferred into small glass vials, and refrigerated at $4^{\circ} \mathrm{C}$ to kill them. After defrosting, they were pinned (Hausmann et al., 2016) and identified to the level of species or genera with the help of the Department of Entomology, University of Agricultural Science, Bengaluru. Later, they were identified insitu. The identified bees were categorized into ground-nesting, cavity-nesting or open-tree-nesting species based on their habitat.

Data analyses: Data from all the observational plots were pooled in order to determine the bee diversity index. Bee abundance was calculated as the total number of individual bees, and species richness was calculated based on the total number of species collected. Bee diversity and richness were quantified using Shannon's diversity index and Simpson's index of dominance. The dominant species was calculated using a rank abundance plot (Makkar and Chhuneja, 2015).

\section{Results and Discussion}

A total of 1699 bees belonging to 19 species under 13 genera were recorded at the study site (Table 1). The population included four species of social bees (Apis dorsata, A. cerana, $A$. florea and Tetragonula iridipennis), five species of solitary bees (Ceratina binghami, Amigella sp., Xylocopa sp., X. pubescens, X. violacea and a kleptoparasite (Thyreushistrio) under Apidae (53\%); five species of solitary bees (Lasioglossum sp.1, Lasioglossum sp.2, Nomia sp., Nomioides sp. and Seladonia sp.) under Halictidae (26\%); and four species of solitary bees (Megachile sp., Megachilelanata, Lithurgus sp. and Heriades sp.) under Meghachelidae (21\%). Bees of family Apidae were the most abundant, represented by cavity-nesting, ground-nesting, and open-tree-nesting social bees and by kleptoparasitic bee species (Table 1). The number of solitary bee species (15 species) was more than that of social bee species (4 species). Similarly, the overall cavity-nesting $(52.6 \%)$ bee species were more common in the studied urban green space than groundnesting $(31.6 \%)$ or open-tree-nesting $(10.5 \%)$ bee species (Fig.1). Tetragonula iridipennis (9.83\%), a cavity-nesting species under Apidae, was the dominant species, followed by open-tree nesting bee $A$. dorsata $(9.12 \%)$ among the social bees, and Lasioglossum sp.1 (7.24\%) and Heriades sp. (7.00\%) were the most abundant among the solitary species (Fig. 2). Lithurgus sp., accounting for $1.29 \%$ of the population, was the least common species in the study area, observed only at a few sites. This could be due to their nutritional preference, the species being a specialist group (Perera and Karunaratne, 2019) with specific foraging requirements. Thus, it is apparent that generalist species that forage on a wide range of floral resources are better adapted to urban areas than specialist species (Minckley et al., 2013). The values of Shannon's diversity index (2.844), Simpson's index of dominance (0.937) and evenness index (0.965) clearly indicated high diversity, species abundance and uniform distribution of bee population in the urban green space.

The values of diversity indices confirmed the abundance, species diversity and uniform distribution of native bee taxa in the urban green area, and indicated the suitability of urban green spaces as potential ecological habitats for diverse bee fauna. Data are scanty on the ecological significance of bees in Indian cities: most of the data are on the pollinating efficiency of bees in agricultural ecosystems. However, studies conducted in non-urban ecosystems have shown the assemblages of native bee spices to be homologous. A study (Balachandra and Bhaviskar, 2016) conducted in Paithan, a town in Maharashtra, India, also documented similar bee

Table 1: List of native bee species recorded in the study area with their distribution status and habitat type

\begin{tabular}{llll}
\hline Family & Scientific name & \% distribution & Life habitat \\
\hline Apidae & Apis dorsata & 9.12 & Social \\
& Apis cerana & 8.30 & Social \\
& Apis florea & 8.65 & Social \\
& Tetragonula iridipennis & 9.83 & Social \\
& Ceratina binghami & 4.53 & Solitary \\
& Amigella sp. & 5.30 & Solitary \\
& Xylocopa violacea & Solitary \\
& Xylocopa pubescens & 4.83 & Solitary \\
& Xylocopa sp. & 4.94 & Solitary \\
& Thyreushistrio & 3.47 & Solitary, kleptoparasite \\
Halictidae & Nomia sp. & 2.59 & Solitary \\
& Nomioides sp. & 2.11 & Solitary \\
& Lasioglossum sp.1 & 3.59 & Solitary \\
Lasioglossum sp.2 & 7.24 & Solitary \\
Seladonia sp. & 4.26 & Solitary \\
Megachile sp. & 5.18 & Solitary \\
& Megachilelanata & 3.83 & Solitary \\
& Heriades sp. & 3.24 & Solitary \\
& Lithurgus sp. & 7.00 & Solitary \\
\hline
\end{tabular}




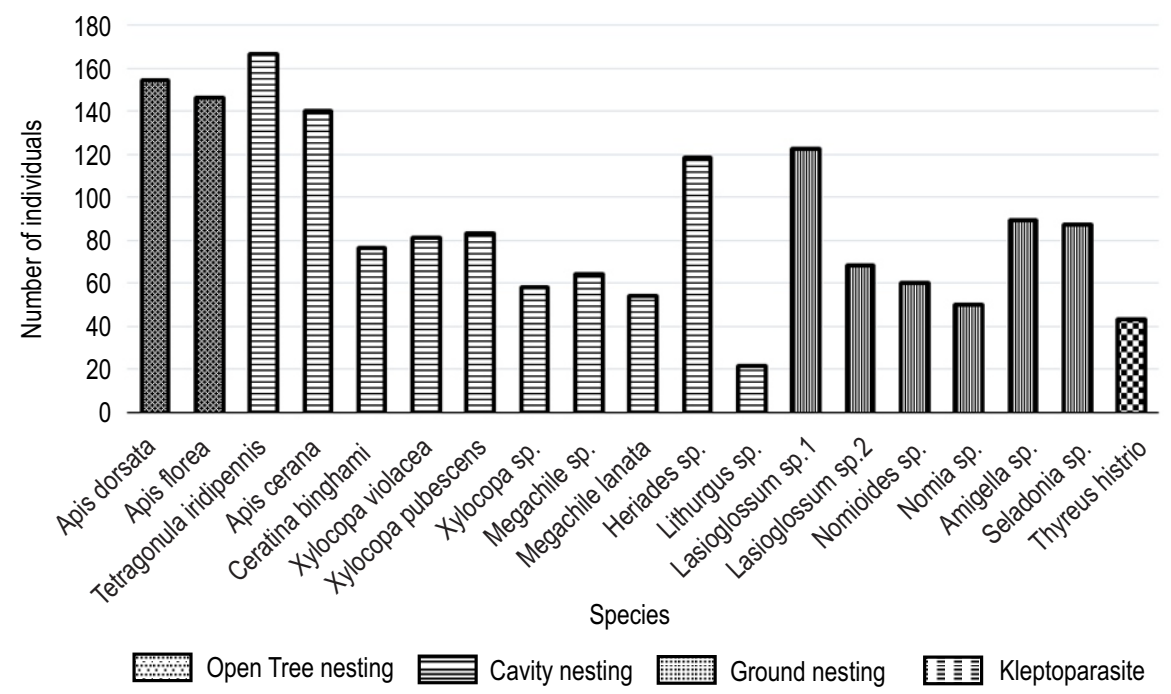

Fig. 1: Diversity and abundance of native bees by their nesting pattern in the study area.

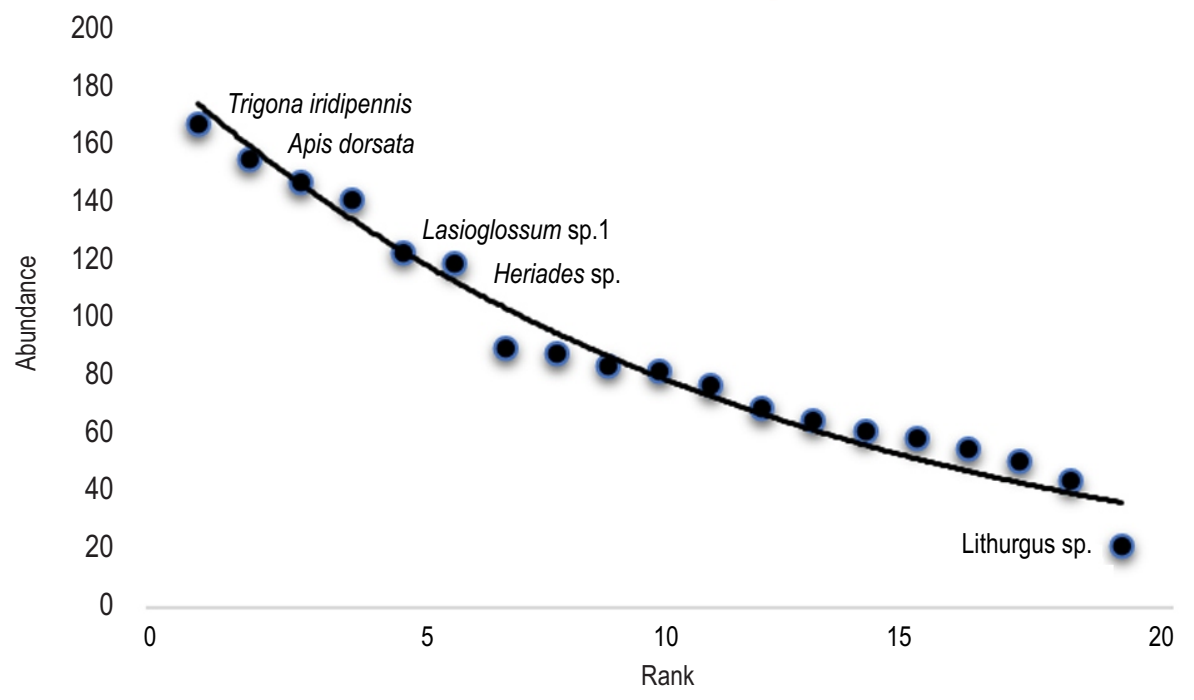

Fig. 2: Rank abundance curve of all the native bee species in the study area.

diversity with 22 native species of bees belonging to 11 genera consisting of 4 social Apis species and 18 solitary bee species under Halictidae and Megachilidae. Similar studies conducted earlier on oilseed crops in Tamil Nadu (Navatha and Sreedevi, 2015) and on Jatropha curcas in Himachal Pradesh (Mattu and Arunkumar, 2013) have also reported 10 species of social native bees and 12 species of native solitary bees under Apidae, Halictidae and Megachilidae. These studies also reported the members of Apidae as the most dominant bee taxa. This confirms the diversity and species richness of bee taxa in urban green areas despite variation in floral composition.
Studies conducted on the nesting habits of social bees in Karnataka have reported the increasing incidence of colonies of social bees in urban habitats. In agreement with the present study, nests of $T$. iridipennis, followed by those of $A$. dorsata and A. florea, in large numbers were reported in Mysore district (Basavarajappa, 2010). Similarly, a study conducted on the nesting preference of $T$. iridipennis in different cities in Karnataka (Nayak et al., 2013) documented significantly more nests in inhabited areas than in natural habitats. This difference shows that social bees now increasingly prefer built structures in cities to farmlands or forest lands (Layek and Karmakar, 2018; Nagaraja, 
2019) and also confirms the availability of feeding resources, nesting sites, and nesting substrate in urban habitats within the specific range of activity of bees (Westrich et al., 1996; Kattwinkel et al., 2011). Additionally, the abundance of cavity-nesting bee species confirms the advantage of nesting sites within built structures. It is, thus, clear that green pockets within urban areas can fully support a diverse community of social and solitary bees and provide adequate nutritional and nesting resources comparable to those provided by non-urban habitats. The studies conducted in urban green spaces in other parts of the world have also shown diverse communities of bee taxa ranging from 54 species in 19 urban gardens in New York (Matteson et al., 2008), 56 species in Vancouver (Tommasi et al., 2004) and 291 bee species from 24 urban localities of Grand Lyon, France (Fortel etal., 2014).

The fewer number of species reported in the present study could be due to relatively short sampling period and the focus on onlyone green space within the city: a longer sampling period and multiple green spaces could have yielded additional species. Studies have also reported increasing numbers of cavity-nesting bees (Cane et al., 2006; Hernandez et al., 2009) as well as small-bodied social bee species (Banaszak-Cibicka and Zmihorski, 2012) in cities. In line with the results of the present study, other studies have documented higher numbers of cavitynesting bees in urban areas (Kearns and Oliveras, 2009; Sirohi et al., 2015; Husmann et al., 2016) than in natural habitats. Diversity studies conducted in green spaces in cities (Frankie et al., 2009), on urban green roofs (Colla et al., 2009) and in semi-urban areas (Seller and Hicks, 2015; Wilson and Jamieson, 2019), have shown Lasioglossum (Choate et al., 2018) and Halictus to be the common species of solitary bees in urban areas, as reported in the present study as well. Together, these studies confirm that cavity-nesting social and solitary bees are better adapted to urban habitats because those bees are able to nest in built structures and also represent adequate diversity in their species composition in such habitats. Urban green spaces, which offer diverse native and exotic flora, can provide sufficient foraging and nesting resources for a large community of native bee species. Therefore, cities are ideal ecological habitats to protect, conserve, and restore the currently declining diversity in native bees. Further, in rapidly developing countries such as India, such spaces can create diverse habitats for native bees. The findings of the present study can be applied in developing pollinator-friendly land uses to protect biodiversity and in turn, the entire urban ecosystem.

\section{Acknowledgment}

The first author would like to acknowledge the help of Dr. Vasuki Belavadi, Professor Emeritus, Entomology Department, University of Agricultural Sciences, Bengaluru, for his invaluable help in bee identification.

\section{References}

Baldock, K.C., M.A. Goddard, D.M. Hicks, W.E. Kunin, N. Mitschunas, L.M. Osgathorpe, S.G. Potts, K.M. Robertson, A.V. Scott, G.N. Stone, I.P. Vaughan and J. Memmott: Where is the UK's pollinator biodiversity? The importance of urban areas for flower-visiting insects. Proc. R. Soc. B., 282, 20142849 (2015).

Banaszak-Cibicka, W. and M. Zmihorski: Wild bees along an urban gradient: Winners and losers. J. Insect. Conserv., 16, 331-343 (2012).

Basavarajappa, S.: Studies on the impact anthropogenic interference on wild honeybees in Mysore District, Karnataka, India. African J. Agric. Res., 5, 298-305 (2010).

Bhalchandra, W. and R.K. Baviskar: Diversity of pollinator bees from Paithantaluka of Aurangabad district (MS) India. J. Entomol. Zool. Stud., 5, 697-700 (2017).

Biesmeijer, J.C., S.P.M. Roberts, M. Reemer, R. Ohlemuller, M. Edwards, T. Peeters, A.P. Schaffers, S.G. Potts, R. Kleukers, C.D. Thomas, J. Settele and W.E. Kunin: Parallel declines in pollinators and insect-pollinated plants in Britain and the Netherlands. Science, 313, 351-354 (2006).

Cane, J. H. and V.J. Tepedino: Causes and extent of declines among native North American invertebrate pollinators: Detection, evidence and consequences. Conserv. Ecol., 5, Article No. 1 (2001).

Cane, J.H., R. Minckley, T. Roulston, L. Kervin and N.M. Williams: Multiple response of desert bee guild (Hymenoptera: Apiformes) to urban habitat fragmentation. Ecol. Appl., 16, 632-644 (2006).

Choate, B.A., P.L. Hickman and E.A. Moretti: Wild bee species abundance and richness across urban-rural gradient. J. Insect. Conserv., 22, 391-403 (2018).

Colla, S.R., E. Willis and L. Packer: Can green roofs provide habitat for urban bees (Hymenoptera: Apidae)?. Cities Environ., 2, Article No. 4 (2009).

Fetridge, E.D., J.S. Ascher and G.A. Langellotto: The bee fauna of residential gardens in a suburb of New York City (Hymenoptera: Apoidea). Ann. Entomol. Soc. Am., 101, 1067-1077 (2008).

Fortel, L., M. Henry, L. Guilbaud, A.L. Guirao, M. Kuhlmann and H. Mouret: Decreasing abundance, increasing diversity and changing structure of the wild bee community (Hymenoptera: Anthophila) along an urbanization gradient. PLOS ONE, 9, e104679(2014).

Frankie, G.W., R.W. Thorp, J. Hernandez, M. Rizzardi, B. Ertter, J.C. Pawelek, S.L. Witt, M. Schindler, R. Coville and V.A. Wojcik: Native bees are a rich natural resource in urban California gardens. Calif. Agric., 63, 113-120 (2009).

Frankie, G.W., R.W. Thorp, M. Schindler, J. Hernandez, B. Ertter and M. Rizzardi: Ecological patterns of bees and their host ornamental flowers in two northern California cities. J. Kans. Entomol. Soc., $78,227-246$ (2005).

Goddard, M.A., A.J. Dougill and T.G. Benton: Scaling up from gardens: Biodiversity conservation in urban environments. Trends Ecol. Evol., 25, 90-98 (2010).

Goulson, D., E. Nicholls, C. Botías and E.L. Rotheray: Combined stress from parasites, pesticides and lack of flowers drives bee declines. Science, 347, DOI: 10.1126/science.1255957 (2015).

Grimm, N.B., S.H. Faeth, N.E. Golubiewski, C.L. Redman, J. Wu, X. Bai and J.M. Briggs: Global change and the ecology of cities. Science, $319,756-760$ (2008).

Gupta, R.K.: The diversity of bees (Hymenoptera, Apoidea) in India. Advancements in insect biodiversity (Ed.: R.K. Gupta). Agrobios, pp. 53-78 (2003).

Harrison, T. and R. Winfree: Urban drivers of plant-pollinator interactions. Funct. Ecol., 29, 879-888(2015).

Hausmann, S.L., J.S. Petermann, J. Rolff, S.R. Leather and M. Heard: Wild bees as pollinators of city trees. Insect. Conserv. Diver., 9, 97107 (2016)

Hernandez, J.L., G.W. Frankie and R.W. Thorp: Ecology of urban bees: A review of current knowledge and directions for future study. Cities 
Environ., 2,360-376 (2009).

Kattwinkel, M., R. Biedermann and M. Kleye: Temporary conservation for urban biodiversity. Biol. Conserv., 144, 2335-2343 (2011).

Kearns, C.A. and M. D. Oliveras: Environmental factors affecting bee diversity in urban and remote grassland plots in Boulder, Colorado. J. Insect. Conserv., 13, 655-665 (2009).

Kevan, P.G.: Pollinators as bioindicators of the state of the environment: Species, activity and diversity. Agric. Ecosyst. Environ., 74, 373393 (1999).

Klein, A.M., B.E. Vaissiere, J.H. Cane, I. Steffan-Dewenter, S.A. Cunningham, C. Kremen and T. Tscharntke: Importance of pollinators in changing landscapes for world crops. Proc. Royal Soc. B., 274, 303-313 (2007).

Kremen, C., N.M. Williams and R.W. Thorp: Crop pollination from native bees at risk from agricultural intensification. Proc. Natl. Acad. Sci, 99, 16812-16816 (2002).

Kremen, C., N.M. Williams, M.A. Aizen, B. Gemmill-Herren, G. LeBuhn, R. Minckley, L. Packer, S.G. Potts, T. Roulston, I. SteffanDewenter, D.P. Vazquez, R. Winfree, L. Adams, E.E. Crone, S.S. Greenleaf, T.H. Keitt, A.M. Klein, J. Regetz and T.H. Ricketts: Pollination and other ecosystem services produced by mobile organisms: A conceptual framework for the effects of land-use change. Ecol. Lett., 10, 299-314 (2007).

Layek, U. and P. Karmakar: Nesting characteristics, floral resources and foraging activity of Trigona iridipennis Smith in Bankura district of WestBengal, India. Insec. Soci., 65, 117-132 (2018).

Makkar, G.S. and P.K. Chhuneja: Diversity assessment of regional crop pollinating bee fauna in ecological perspective. Eco. Envo. Cons., 21, 1811-1816 (2015).

Matteson, K.C., J.S. Ascher and G.A. Langellotto: Bee richness and abundance in New York City urban gardens. Ann. Entomol. Soc Am. 101,140-150 (2008).

Mattu, V.K. and A. Kumar: Diversity and relative abundance of solitary bees on Jatropha curcas crop in Sirmour and Solan Hills of Himachal Pradesh, India. Int. J. Sci. Res., 5, 1815-1818 (2013).

McDonald, R.I., P. Kareiva and R.T.T. Formana: The implications of current and future urbanization for global protected areas and biodiversity conservation. Biol. Conserv., 141, 1695-1703 (2008).

Michener, C.D.: The Bees of the World. $2^{\text {nd }}$ Edn., The Johns Hopkins University Press, Baltimore and London, USAand UK (2007).

Minckley, R.L., T.H. Roulston and N.M. Williams: Resource assurance predicts specialist and generalist beeactivity in drought. Proc. Biol. Sci., 280, 20122703 (2013).

Nagaraja, N.: Nesting patterns of giant honeybee, Apisdorsata in plains of Karnataka, India. J. Entomol. Res., 43, 503-508 (2019).

Navatha, L. and K. Sreedevi: Pollinator diversity of solitary bees in oilseed crops. Curr. Biotica., 8, 375-381 (2015).

Nayak, P.P., M.S. Reddy and Jayaprakash: Strategic adaptation of Trigona iridipennis (Hymenoptera: Apidae: Meliponini) in human-inhabited areas of Karnataka, India. Multi. Logic. In. Sci., 2, 18-26 (2013).

Osborne, J.L., I.H. Williams and S.A. Corbet: Bees, pollination and habitat change in the European Community. Bee World, 72 , 99-116 (1991).

Otto, C.R.V., C.L. Roth, B.L. Carlson and M.D. Smart: Land-use change reduces habitat suitability for supporting managed honey bee colonies in the Northern Great plains. Proc. Natl. Acad. Sci. USA,113, 10430-10435 (2016).

Pardee, G.L. and S.M. Philpott: Native plants are the bee's knees: Local and landscape predictors of bee richness and abundance in backyard gardens. Urban Ecosyst., 17,641-659 (2014).

Perera, R.A.S.N. and I. Karunaratne: Floral visits of the wild bee, lithurgusatratus, impact yield and seed germinability of okra, Abelmoschus esculentus, in Sri Lanka. J. Pollinat. Ecol., 25, (2019).

Potts, S.G., B. Vulliamy, A. Dafni, G. Ne'eman and P. Willmer: Linking bees and flowers: How do floral communities structure pollinator communities?. Ecology, 84, 2628-2642 (2003).

Reddy, P.R., T. Rashmi and A. Verghese: Foraging activity of Indian honey bee Apis cerana, in relation to ambient climate variables under tropical conditions. J. Environ. Biol., 36, 577-581 (2015).

Savard, J.P.L., P. Clergeau and G. Mennechez: Biodiversity concepts and urban ecosystems. Landsc. Urban Plan., 48, 131-142 (2000).

Seller, R. and B. Hicks: Bee diversity and abundance in three different habitats of eastern New found land. J. Acad. Entomol. Soc.,11, 914 (2015).

Senapathi, D., G.Carvalheiro, J.C. Biesmeijer, C. Dodson, R.L. Evans and M. Mckerchar: The impact of over 80 years of land cover changes on bee and wasp pollinator communities in England. Proc. Roy. Soc. Biol. Sci., 282 (2015). DOl: 10.1098/rspb.2015.0294

Sirohi, M.H., J. Jackson, M. Edwards and J. Ollerton: Diversity and abundance of solitary and primitively eusocial bees in an urban centre: A case study from Northampton (England). J. Insect. Conserv., 19, 487-500 (2015).

Tomassi, D., A. Miro, H.A. Higo and M.L. Winston: Bee diversity and abundance in an urban setting. Can. Entomol., 136, 851-869 (2004).

Tonietto, R., J.Fant, J.Ascher, K. Ellis and D. Larkin: A comparison of bee communities of Chicago green roofs, parks and prairies. Landsc. Urban Plann., 103, 102-108 (2011).

Westphal, C., R. Bommarco, G. Carré, E. Lamborn, N. Morison, T. Petanidou, S.G. Potts, S.P.M. Roberts, H. Szentgyörgyi, T. Tscheulin, B.E. Vaissière, M. Woyciechowski, J.C. Biesmeijer, W.E. Kunin, J. Settele and I. Steffan-Dewenter: Measuring bee diversity in different European habitats and biogeographical regions. Ecol. Monogr., 78, 653-672 (2008).

Westrich, P., A. Matheson, S.L. Buchmann, C. O'Toole, P. Westrich and I.H. Williams: Habitat requirements of central European bees and the problems of partial habitats. The conservation of bees. London, Academic Press, 18, 1-16 (1996).

Williams, N.M. and C. Kremen: Resource distributions among habitats determine solitary bee offspring production in a mosaic landscape. Ecol.Appl., 17, 910-921 (2007).

Williams, N.M., E.E Crone, T'ai H. Roulston, R.L. Minckley, L. Packer and S.G. Potts: Ecological and life-history traits predict bee species responses to environmental disturbances. Biol. Conserv., 143, 22802291 (2010).

Williams, N.S.G., M.W. Schwartz, P.A. Vesk, M.A. McCarthy, A.K. Hahs, S.E. Clemants, R.T. Corlett, R.P. Duncan, B.A. Norton, K. Thompson and M.J. Mcdonnell: A conceptual framework for predicting the effects of urban environments on floras. J. Ecol., 97, 4-9 (2009).

Wilson, C.J. and M.A. Jamieson: The effects of urbanization on bee communities depends on floral resource availability and bee functional traits. PloS ONE, 14, e0225852 (2019).

Winfree, R., R. Aguilar, D.P. Vázquez, G. LeBuhn and M.A. Aizen: A meta-analysis of bees' responses to anthropogenic disturbance. Ecology, 90, 2068-2076 (2009).

Winfree, R., T. Griswold and C. Kremen: Effect of human disturbance on bee communities in a forested ecosystem. Conserv. Biol., 21, 213-223 (2007).

Zapparoli, M.: Urban development and insect biodiversity of the Rome area, Italy. Landsc. Urban Plann., 38, 77-86 (1997). 